\title{
CREAM-COLOURED AND GREEN-COLOURED LINES OF THE NONMORPHOGENIC CALLUS OF PLANTAGO ASIATICA L. - ULTRASTRUCTURE ANALYSIS
}

\author{
JOANNA MAKOWCZYŃSKA ${ }^{1}$, \\ EMILIA ANDRZEJEWSKA-GOLEC ${ }^{1}$, KRYSTYNA MAREK ${ }^{2}$ \\ ${ }^{1}$ Department of Biology and Pharmaceutical Botany \\ Medical University of Łódź \\ Muszyńskiego 1, 90-151 Łódź, Poland \\ e-mail: e.andrzejewska@wp.pl \\ 2 Department of Electron Microscopy \\ Medical University of Łódź \\ Czechosłowacka 8/10, 92-216 Łódź, Poland
}

(Received: December 6, 2004. Accepted: March 10, 2005)

\begin{abstract}
The ultrastructure of two lines of nonmorphogenic Plantago asiatica callus was compared. The ultrastructure of most organelles of cream-coloured and green-coloured lines of these callus lines was similar. Among the plastides no difference in prevalence and composition of proplastides and amyloplasts was observed. The main difference lies in the presence of chlororoplasts in green callus. The phenomena of vacuolisation and tracheogenesis in both lines were found.
\end{abstract}

KEY WORDS: Plantago asiatica, callus, ultrastructure.

\section{INTRODUCTION}

The range of Plantago asiatica L. occurrence comprises the Far East countries (Yamazaki 1993). It has been applied there as a valuable medicinal plant (AndrzejewskaGolec 1994). In Europe this species is known only from some botanical gardens.

A callus of Asiatic plantain was obtained for the first time by Yisheng (1996). It was a morphogenic callus regenerating plantlets. We have obtained nonmorphogenic, morphogenic and embryogenic calluses of this plant (Makowczyńska and Andrzejewska-Golec 2000) and also regenerated plants both indirectly and via callus (Andrzejewska-Golec and Makowczyńska 2001; Makowczyńska and Andrzejewska-Golec 2003). In earlier works we described plastids and tracheary elements of $P$. asiatica callus tissue (Andrzejewska-Golec et al. 2004; Makowczyńska et al. 2004). The aim of this study was to compare the ultrastructure of two lines of the nonmorphogenic Asiatic plantain callus.

\section{MATERIAL AND METHODS}

The method of obtaining $P$. asiatica callus culture is presented in Scheme 1.
The methods of the ultrastructure study are presented in Scheme 2.

\section{RESULTS}

The cream-coloured callus was formed in the presence of cytokinin BAP $\left(0.2 \mathrm{mg} / \mathrm{dm}^{3}\right)$ and auxine IAA $(0.1$ $\left.\mathrm{mg} / \mathrm{dm}^{3}\right)$. Green-coloured callus was formed in the presence of $2 \mathrm{mg} / \mathrm{dm}^{3}$ BAP and auxine 2,4-D in concentration 0,5 $\mathrm{mg} / \mathrm{dm}^{3}$.

The cream-coloured callus and green-coloured callus of $P$. asiatica have a similar nodular structure (Figs 1,2) and similar ultrastructure (Figs 3-14).

Cell walls of both lines of the callus culture have a typical structure (Figs 3, 5). They are above all primary cell walls. The cells are usually precisely connected with the thin middle lamellae. The plasmodesmata are not numerous (Fig. 13). Secondary cell walls were formed during xylogenesis. The tracheogenesis was occurred in the both analysed lines of Plantago asiatica callus (Fig. 10). We observed only reticulate and helical thickenings of the secondary wall of tracheary elements. The xylogenesis is accurately described in the earlier work (Andrzejewska-Golec et al. 2004). Irregularly thickened middle lamellae were sometimes observed. They degenerate and dissolve during 
SCHEME 1.

Plantago asiatica $\mathrm{L}$. in in vitro culture

seeds

(source: Botanical Gardens, Faculty of Science, University of Tokyo)

in vitro germination in dark

$\mathrm{MS}+0.2 \mathrm{mg} / \mathrm{dm}^{3} \mathrm{~K}+1 \mathrm{mg} / \mathrm{dm}^{3} \mathrm{GA}_{3}$

$\downarrow$

4 week-old seedlings (source of primeval explants)

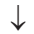

root

passage 0 in light

$\mathrm{MS}+0.5 \mathrm{mg} / \mathrm{dm}^{3} 2.4-\mathrm{D}+0.2 \mathrm{mg} / \mathrm{dm}^{3} \mathrm{BAP}$

$\downarrow$

cream-coloured callus line

successive passages in ligh

$\mathrm{MS}+0.5 \mathrm{mg} / \mathrm{dm}^{3} 2.4-\mathrm{D}+0.2 \mathrm{mg} / \mathrm{dm}^{3} \mathrm{BAP}$

$\downarrow$

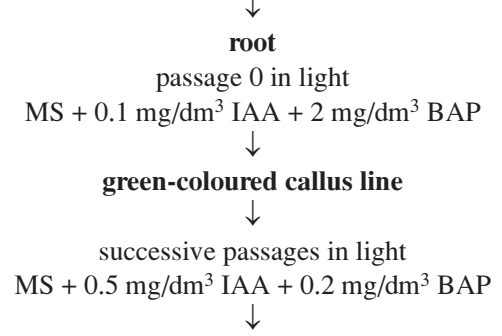

Explanations to Scheme 1.

MS - Murashige and Skoog medium

$\mathrm{K}$ - kinetin

GA - gibberellic acid

2,4-D - 2,4-dichlorophenoxyacetic acid

BAP - 6-benzylaminopurine

IAA - indole-3-acetic acid

SCHEME 2.

Samples of material: the pieces of cream-coloured callus tissue (7. passage) and green-coloured callus tissue (14. passage)

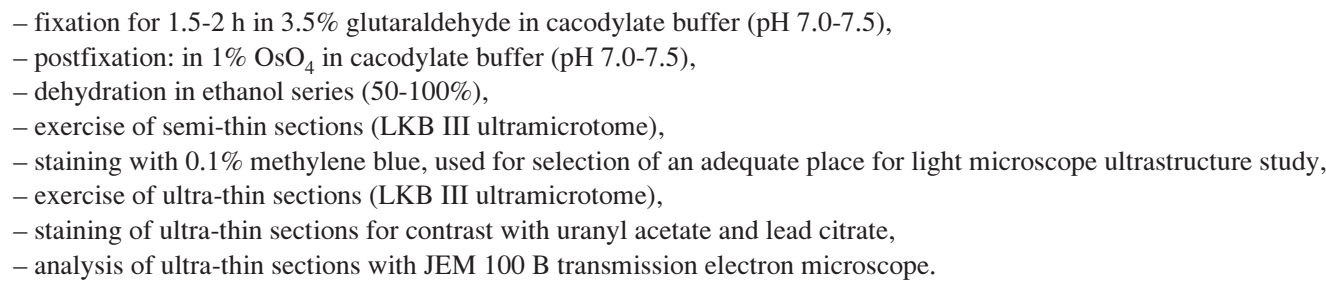

formation of intracellular spaces (Fig. 11). The electrondense fibrillar material can be observed in some intracellular spaces.

Ribosomes. The cells of both studied lines of the callus are rich in free ribosomes and also in polisomes (Figs 7, 8, $13,14)$.

Endoplasmic reticulum (rough endoplasmic reticulum and smooth endoplasmic reticulum) is comparatively weakly developed in both callus lines (Fig. 8).

Dictyosomes, mitochondria and nuclei have a similar ultrastructure in both callus lines. Dictyosomes are typically formed with 3-7 cysterns and do not have numerous vesicles of Golgi (Fig. 14). Mitochondria (with tubuli and sacculi) are numerous (Figs 5-7), sometimes multiform (Figs 6, 9). Some of them are ring-shaped (Fig. 6), also strongly elongated (Fig. 9). We also observed dividing mitochondria.

Nuclei are multiform in shape (Figs 1-3, 9, 10), also lobed (Figs 4, 6, 7), with numerous pores in the nuclear membrane (Fig. 6) and with irregular dispersed chromatin (Figs 3-5, 9).Nucleoli are usually prominent (Figs 3-6, 9), with granular structure (Fig. 8) and one or more "nucleolar vacuoles" (Figs 4, 6, 8). Only sporadically we observed two nucleoli in the nucleus.

Vacuoles. Meristematic and young parenchymatic cells of callus have numerous small vacuoles (Figs 4, 5, 9). Old parenchymatic cells are highly vacuolated (Figs 10, 12). In large vacuoles, we observed different cell elements or their fragments (Fig. 9), also the phagocytosis phenomenon cell organelles inside the tonoplast invagination. Strongly vacuolated moribund cells were also found. This phenomenon occurs in cell reorganisation during formation of tracheary elements (Fig. 10).

Plastids. In cream-line and green-line callus we observed proplastids (Figs 3, 5, 9) and amyloplasts (Figs 9, 11), but chloroplasts were seen only in green-line callus (Figs 10, 12). Phytoferritin in plastids was not observed. Amyloplasts contain one or some starch grains and rudimentary thylakoid membranes. Chloroplasts are typical structures with small starch grains and small dark plastoglobuli in stroma. The prevalence of plastids in the callus tissue of $P$. asiatica and steps of their ontogenesis are presented in a separate publication (Makowczyńska et al. 2004).

Numerous lipid body-like structures were present in cytoplasm in both lines of the callus (Fig. 3).

\section{DISCUSSION}

An in vitro culture of callus is commonly obtained, but only some authors have studied its ultrastructure.

The cream-coloured callus and green-coloured callus of $P$. asiatica have a similar ultrastructure. This main difference lies in the presence of chloroplasts in green callus. 


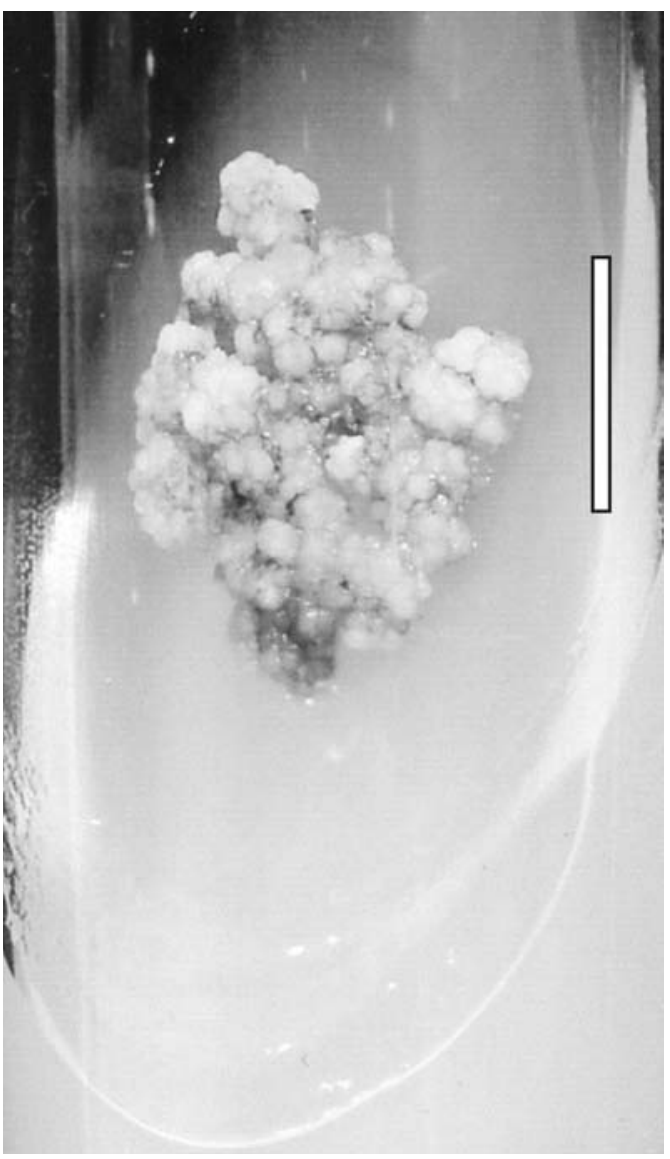

Fig. 1. Cream-coloured callus of Plantago asiatica L. Scale bar $1 \mathrm{~cm}$.

Parts of cells of both lines of nonmorphogenic callus of plantain are characterised by intensive metabolism, which is evidenced by large nuclei with prominent nucleoli including "nucleolar vacuoles", numerous ribosomes and poliribosomes as well as numerous mitochondria. Stępiński and Kwiatkowska (2001) supposed that large "vacuoles" in central position of nucleoli might in consequence form intensive transposition of granular compounds from nucleolus to cytoplasm. Gwóźdź et al. (1974) observed in IAAtreated callus tissue of Cichorium intybus a remarkable development of the granular endoplasmic reticulum and an increase in number of ribosomes, mainly in the form of polyribosomes. With abundance of ribosomes, the size, "vacuolisation" and granular structure of nucleoli coincidentally increased. According to these authors, such changes in nuclei are considered to represent the first step of increased growth activity of cells in response to growth regulators. After Mikuła et al. (2002), symptoms of increased metabolism activity in the cell are enlarged, with centrally located nuclei of the granular structure containing large nucleoli with "nucleolar vacuoles" inside. According to these authors such structure is an evidence of an increased synthesis of RNA and is typical for cells getting ready for cell divisions or for embryogenic callus tissue formation.

Lobeled nuclei (nuclei with deep invaginations of the nuclear envelope) observed by us in callus cells of $P$. asiatica are described by other authors, for example: Poljuha et al. (2003) in shoot cells of Mammillaria gracilis cultivated in vitro, and Mól and Sierżant (2001) in maize antipodal cells.

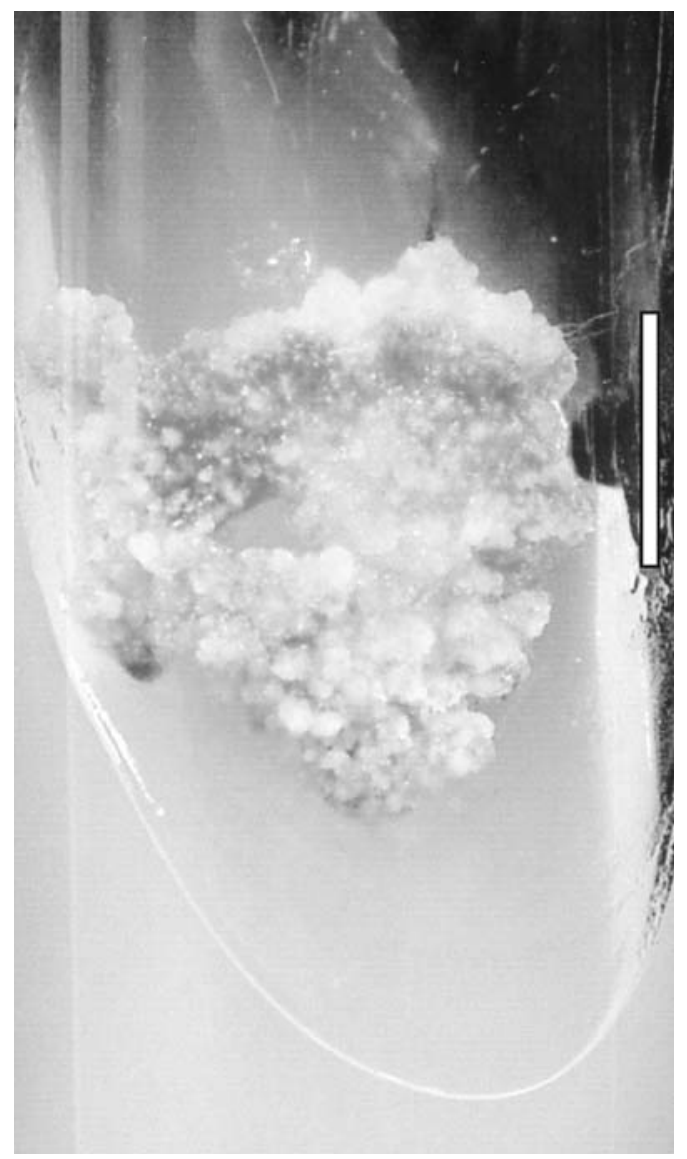

Fig. 2. Green-coloured callus of Plantago asiatica $\mathrm{L}$. Scale bar $1 \mathrm{~cm}$.

All kinds of plastids in cream-coloured and green-coloured lines of $P$. asiatica callus are very variable in this ultrastructure. Poljuha et al. (2003) give attention to plastids as very sensitive plant cell organelles reacting to the artificial environment in the culture.

Green colour of callus is associated with chloroplast differentiation. After Caredda et al. (2004), in the microspore-derived callus of barley regenerating albino plantlets, all the plastides are non-dividing amyloplasts with scarce thylakoids.

The cytodifferentiation was found to appear in the callus: we observed numerous tracheary elements in both lines of callus. It is a frequent phenomenon observed in morphogenic and nonmorphogenic callus (Andrzejewska et al. 2004). Gatz and Reinke (2004) reported $100 \%$ of xylogenesis in the callus of pepper when concentration of cytokinine was $0.5 \mathrm{mg} / \mathrm{dm}^{3}$ (with or without IAA). We noticed, first of all, reticulate and rarely helical thickenings of the secondary wall of tracheary elements. The occurrence of this type of thickening is characteristic for vascular elements in callus (Gatz and Reinke 2004). We observed deep transformation of parenchymatic cells in tracheary elements. The phenomenon of intensive digestion occurred in vacuoles that play the part of lisosomes.

\section{CONCLUSIONS}

1. The ultrastructure of most organelles of cream-coloured and green-coloured lines of Asiatic plantain callus is similar. 

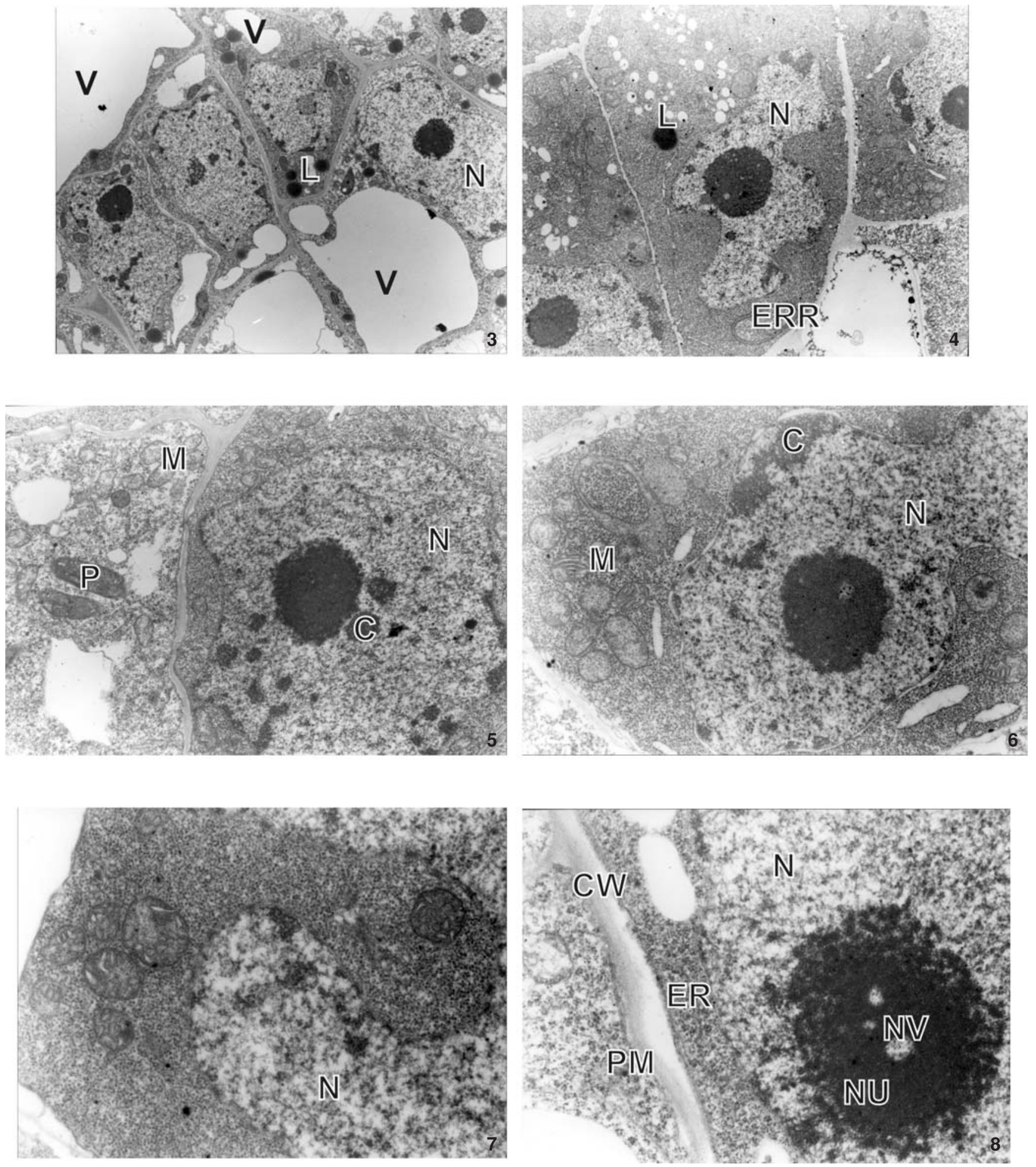

Figs 3-8. Ultrastructure of cream-coloured callus of Plantago asiatica $\mathbf{L}$.

Fig. 3. Various steps of vacuolisation of callus cells, $\times 7500$.

Fig. 4. A lobate nucleus, $\times 10000$.

Fig. 5. A nucleus with large irregular nubs of chromatin, $\times 20000$.

Fig. 6. A nucleus lobe with a nucleolus, $\times 25000$.

Fig. 7. A cytoplasmic invagination in lobate nucleus, $\times 37000$.

Fig. 8. A nucleolus with granular structure and "vacuoles", $\times 37000$.

Explanations to Figures 3-14

A - amyloplast; C - chromatin; CH - chloroplast; CW - cell wall; D - dictyosome; ER - endoplasmic reticulum; ERR - ring endoplasmic reticulum; L lipid drop; M - mitochondrion; ML - middle lamella; N - nucleus; NU - nucleolus; NV - nucleolar "vacuole"; P - proplastid; PD - plasmodesmata; PM plasmalemma; S - starch grain; T - thylakoids; TE - tracheary element; V - vacuole 

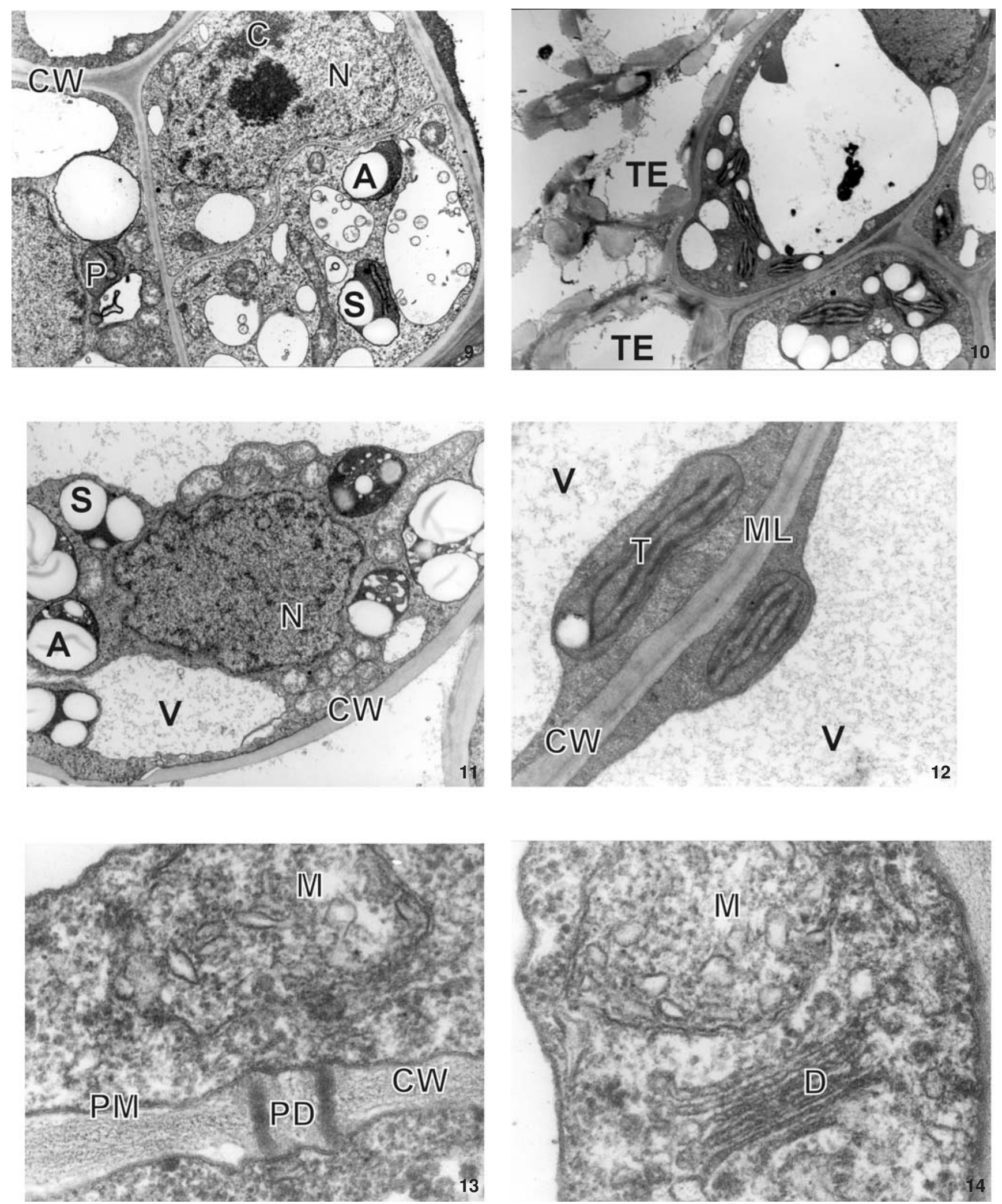

Figs 9-14. Ultrastructure of green-coloured callus of Plantago asiatica $\mathbf{L}$.

Fig. 9. Cells with proplastids and amyloplasts, $\times 12500$.

Fig. 10. Cells with chloroplasts, $\times 7500$.

Fig. 11. Amyloplasts, $\times 10000$.

Fig. 12. Chloroplasts in strongly vacuolated cells, $\times 20000$.

Fig. 13. Plasmodesmata, $\times 125000$.

Fig. 14. Dictyosome, $\times 125000$. 
2. For the cream-coloured callus two types of plastids are characteristic: proplastides and amyloplasts, for green-coloured callus also chloroplasts.

3. Green colour of callus is associated with chloroplast differentiation.

4. The phenomena: division of the cells, vacuolisation, degradation of protoplast and tracheogenesis are very frequently in cream-coloured and green-coloured lines of the nonmorphogenic Plantago asiatica callus.

\section{ACKNOWLEDGEMENTS}

The work is financed by the fund Medical University of Lodz, No. 502-13-222.

\section{LITERATURE CITED}

ANDRZEJEWSKA-GOLEC E. 1994. Babkowate (Plantaginaceae) rośliny lecznicze. Farm.Pol. 50: 899-905. (in Polish with English summary)

ANDRZEJEWSKA-GOLEC E., MAKOWCZYŃSKA J. 2001. Różnicowanie pędów z tkanki kalusowej Plantago asiatica L. In: Botanika w dobie biologii molekularnej, Materiały sesji i sympozjów 52. Zjazdu PTB. Zenkteler E. (ed.). Poznań, p. 159. (in Polish)

ANDRZEJEWSKA-GOLEC E., MAKOWCZYŃSKA J., MAREK K. 2004. Tracheogeneza w tkance kalusowej Plantago asiatica L. Biotechnologia 65: 267-274. (in Polish with English summary)

CAREDDA S., DEVAUX P., SANGWAN R.S, PROULT I., CLEMENT C. 2004. Plastid ultrastructure and DNA related to albinism in androgenic embryos of various barley (Hordeum vulgare) cultivars. Plant Cell Tiss. Org. Cult. 76: 35-43.

GATZ A., REINKE M. 2004. Wpływ IAA i BAP oraz warunków świetlnych na różnicowanie kalusa papryki in vitro. Biotechnologia 65: 176-184. (in Polish with English summary)
GWÓŹDŹ E., WOŹNY A., SZWEJKOWSKA A. 1974. Induction by Auxin of Polyrybosomes and Granular Endoplasmatic Reticulum in the Callus Tissue of Cichorium intybus. Biochem. Physiol. Pflanzen 165: 82-92.

MAKOWCZYŃSKA J., ANDRZEJEWSKA-GOLEC E. 2000. Somatic embryogenesis in in vitro culture of Plantago asiatica L. Acta Soc. Bot. Pol. 69: 245-250.

MAKOWCZYŃSKA J., ANDRZEJEWSKA-GOLEC E. 2003. Micropropagation of Plantago asiatica L. through culture of shoot-tips. Acta Soc. Bot. Pol. 72: 191-194.

MAKOWCZYŃSKA J., ANDRZEJEWSKA-GOLEC E., MAREK K. 2004. Plastydy w tkance kalusowej Plantago asiatica L. Biotechnologia 65: 275-281. (in Polish with English summary)

MIKUŁA A., TYKARSKA T., RYBCZYŃSKI J., KURAŚ M. 2002. Ultrastructural analysis of initial stages of dediferentiation of root explants of Gentiana cruciata seedlings. Acta Soc. Bot. Pol. 71: 287-297.

MÓL R., SIERŻANT M. 2001. Ultrastruktura antypod kukurydzy w różnych stadiach receptywności kwiatostanu żeńskiego. In: Botanika w dobie biologii molekularnej. Materiały sesji i sympozjów 52. Zjazdu PTB. Zenkteler E. (ed.). Poznań, p. 20. (in Polish)

POLJUHA D., BALEN B., BAUER A., LJUBEŠIĆ N., KRSNIK-RASOL M. 2003. Morphology and ultrastructure of Mammillaria gracillis (Cactaceae) in in vitro culture. Plant Cell, Tiss. Org. Cult. 75: 117-123.

STĘPIŃSKI D., KWIATKOWSKA M. 2001. Ultrastrukturalne i autoradiograficzne badania jąderek w komórkach merystematycznych korzeni soi podczas stresu chłodu i regeneracji. In: Botanika w dobie biologii molekularnej. Mat. sesji i sympozjów 52. Zjazdu PTB. Zenkteler E. (ed.). Poznań, p. 24. (in Polish)

YAMAZAKI T. 1993. Plantaginaceae. In: Flora of Japan. Iwatsuki K. et al. (eds). Kodansha LTD, Tokyo. Vol. 3. pp. 184-186.

YISHENG T. 1996. Tissue culture of Asiatic plantain (Plantago asiatica). Zhongcaoyao 27: 296-298. (in Chinese with English summary) 